\title{
軟骨下骨の欠損を伴う骨軟骨症の黑毛和種子牛の一例
}

\author{
岡田ら ${ }^{1)}$ 今井直人 ${ }^{1)} \quad$ 安藤貴朗 $^{1)} \quad$ 小比類巻正幸 ${ }^{2)}$

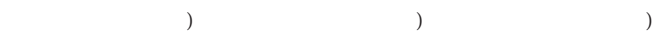 \\ ${ }^{1)}$ 北里大学獣医学部獣医学科, ${ }^{21}$ 小比類巻家畜診療サービス
}

\section{Osteochondrosis with subchondral bone deficit in a Japanese black calf}

\author{
R. Okada ${ }^{1)}, \mathrm{N} \cdot$ Imai $^{1)}, \mathrm{T} . \mathrm{Ando}^{1 *)}, \mathrm{M} . \mathrm{Kohiruimaki}^{2)}$, \\ H. Ohtsuka ${ }^{1)}$ D. Watanabe ${ }^{1)}$ and M. Oikawa ${ }^{11}$ \\ ${ }^{1)}$ School of Veterinary Medicine, Kitasato University \\ ${ }^{2)}$ Kohiruimaki A nimal Medical Service
}

\begin{abstract}
要 約軟骨下骨の欠損を伴う骨軟骨症の黑毛和種子牛についてロ 弚の検査と治療の概要について 報告した口症例は41日齢で 来院時には右前肢腕節に疼痛口腫脹口 熱感がみられ口右前肢に負重は認め られなかった口X線検査では口右前肢第三中手骨近位端に直径約 $1 \mathrm{~cm}$ 囊胞状のX線透過性え進像がみ られた口関節液は白濁していたが細菌培養検査は陰性であった口これらの結果より骨軟骨症と診断しロ 入院 3 日目から関節内の洗浄および消炎剂の関節内投与を行ったが症状の改善はみられなかったロ 39 日目のX線検査で病変部の拡大か認められたため関節鏡手術により病変部全体を掻爬ロ洗浄しロヒア ルロン酸ナトリウムを 1 週間ごとに 4 回 関節内に投与したロ 術後は徐々に症状が改善しロ 67日目のX 線検査では病変部の縮小と骨組織の充実か認められ口跛行を示さなくなった口本症例では消炎斉投与に よる治療では口病態の良化は認められなかったことから口病変部の骨口軟骨の壞死により疼痛を生じて いたと考えられた口関節鏡を用いた壊死病変の掻爬とヒアルロン酸ナトリウムの関節内投与は口 疼痛の 改善口 関節軟骨の修復や保護口 粘弾性の回復などにより牛の骨軟骨症に有効な治療法だと考えられた口 —キーワード : 関節鏡視下手術 ヒアルロン酸ナトリウムロ 黑毛和種子牛口骨軟骨症
\end{abstract}

家畜臨床誌３1( 3):154-159, 2008

ABSTRACT We reported on the examination and treatment of osteochondrosis with subchondral bone deficit in a Japanese black calf. The 41-day-old calf had severe pain, swelling and heat sensation in the right for elimb carpus, and it could not bear weight on the limb. The calf showed a radiolucent area of diameter about $1 \mathrm{~cm}$ from the proximal end of the third metacarpal bone of the right forelimb in X-ray examination. The synovial fluid was turbid, but bacteria were not observed. Based on these results, we diagnosed osteochondrosis with subchondral bone deficit. On Day 3 after admission, the joint was washed with saline solution, and an anti-inflammatory drug was injected into the joint, but this did not alleviate the symptoms. As an enlarged lesion was observed in X-ray examination on Day 39, curettage and washing were performed through arthroscopic surgery, and intra-articular weekly injections of hyaluronate sodium were administered for 1 month. A fter the arthroscopic surgery, there was gradual improvement in the symptoms, and repair and osteogenesis in the lesion were seen in X-ray examination on Day 67.

Received 21 A ugust 2008/ A ccepted 17 September 2008

* Correspondence to : T. A ndo, School of Veterinary Medicine, Rakuno Gakuen University, 582, Modori-machi, Bunky odai, Ebetsu, 069-8501, Japan ( T 069-8501 北海道江別市文京台緑町582 酪農学園大学獣医学部獣医学科)

E-mail : ando@rakuno.ac.jp 
Weight-bearing by the right forelimb improved. As the anti-inflammatory drug had no effect on remission of the symptoms, it appeared that the severe pain was caused by necrosis of bone and cartilage. Curettage and washing through arthroscopic surgery to remove the lesion and intraarticular injection of hyaluronate sodium contributed to the elimination of pain, the repair and conservation of articular cartilage, and the restoration of synovial fluid.

Key Words : arthroscopic surgery, hyaluronate sodium, Japanese black calf, osteochondrosis Jpn. J. V et. Clinics 31( 3) :154159, 2008

緒 言

骨軟骨症は口 ヒトや多くの動物において関節・骨端軟 骨複合体 ( 成長中の長骨端を覆っている未成熟な関節軟 骨) および成長板の双方に起こる多中心性の骨端軟骨の 疾患であるロ ヒトロ 若齢馬では骨軟骨症についての報告 は多いが $[2,11,12] \square$ 牛での報告は少ない口牛におい て発症年䶚は15〜18ヶ月齢での報告例が多いが [ 8 ] 1 １0ケ月齢においても散発している $[7,13,15]$ 発 症部位は膝関節口肘関節で多く～肩関節口球節における 病変も報告されている $[7,8,13,15]$ 口発症初期には関 節の腫脹がみられ口病状が進行すると跛行を示す [ 7, 13] 病理所見としては口骨口軟骨の変性 壊死 欠損口 関節包の線維化口滑膜の䋐毛の肥大などが報告されてい る [ 8] 今回〜軟骨下骨の欠損が生じた骨軟骨症の黑 毛和種子牛の症例に遭遇したため口 その検査所見および 治療口 経過について報告する口

\section{症 例}

症例は41日齢の黑毛和種雄子牛で 右前肢腕節部が腫 脹し跛行か認められたため口2008年 2 月26日に本学大動 物診療センターに来院した口 来院前には臨床検査以外に 治療は行われていなかった口

来院時の体重は $45 \mathrm{~kg} \square$ 体温は $39.2^{\circ} \mathrm{C} \square$ 心拍数は96回/ $\min$ 呼吸数は12回/minであった口 食欲口哺乳欲口活気 はあつたが 右前肢腕節に疼痛口腫脹口熱感がみられた口 右前肢は負重せずロ支柱肢跛行を示していた口 X線検査 所見より口右前肢第三中手骨の近位端に直径約 $1 \mathrm{~cm} の$ 囊胞状のX線透過性方進像がみられた（図１）！血液検 査では口 単球数が増加を示し口 $A / G$ 比が低下を示した (表 1 )、関節液は白濁していたが 血液寒天培地による 48時間の細菌培養検査では陰性であつた口 また口関節液 の塗抹標本では口 好中球主体の炎症細胞の浸潤がみられ たロ

入院中は患部に負荷をかけないよう運動を制限したロ 治療の概要口疼痛と負重の評価（4段階）について図 2

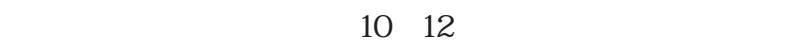
ディエーターや炎症産物の除去を目的としてい 注射針
（18G）を患部の関節内に穿刺し口生理食塩水1 $\ell$ にマイ シリン (懸濁水性マイシリンロ日本全薬工業口福島) 100万単位を添加したもの100〜200mlにより関節内を洗 浄し口患部への経皮鎮痛消炎剂（インテバン軟膏 大日 本住友製薬口大阪) および血行促進剂(ヒルドイドロマ ルホロ 大阪) の塗布を行ったロ入院 3 日目に洗浄後口プ レドニゾロン (プレドニゾロンロ 川崎三鷹製薬口神奈川) $5 \mathrm{mg}$ を関節内投与したが口 疼痛の軽減がみられなかっ たためロ 入院 4〜6! 10] 12日目にはフルニキシン (フォー ベットロ シェリング・プラウ アニマルヘルスロ 東京) $25 \mathrm{mg}$ を関節内投与した口一時的に疼痛口跛行の改善が みられたが、入院16日目には再びロ 疼痛口跛行の悪化が みられためロ 関節内の洗浄およびフルニキシンの関節内 投与を行った口关の後も強い疼痛が続いたためロ 関節内 の洗浄とともにロ入院18ロ20日目には塩酸リドカイン (キシロカイン注射液 $2 \%$ アアストラゼネカロ 大阪) 4 mgを関節内投与したが状態に変化はみられなかった口 入院23!24日目に再度フルニキシン15mgを関節内投与 したロ その後も経過を観察したが患部の疼痛口腫脹口 熱感口患肢への負重の改善はみられず口 関節液は白濁し たままであったロ入院39日目のX線検査所見で雖胞状 の病変部は来院時と比べ拡大していたため ( 図 3 ) ? 病
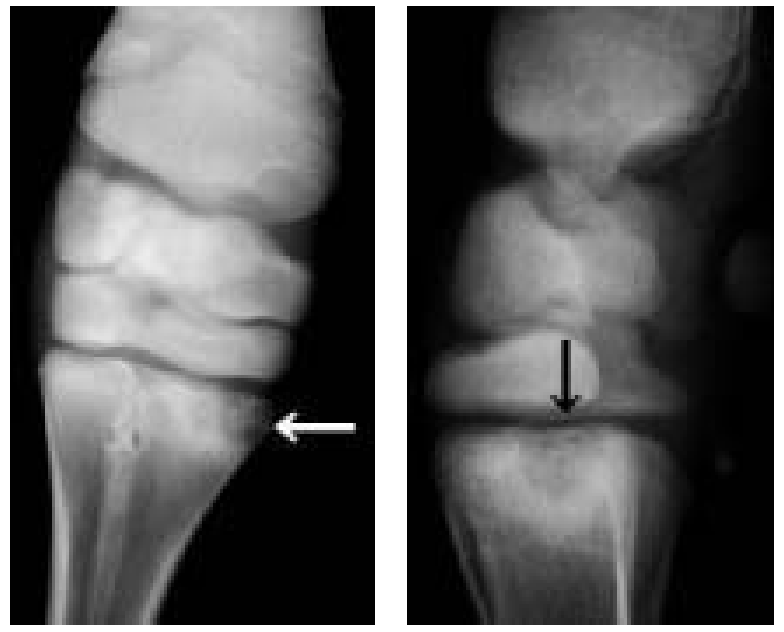

図1，右腕節X 線像：来院時

(左：頭尾方向，右：横方向)

矢印：第三中手骨の欠損がみられる(病変部) 
表1．来院時の血液性化学検査所見

\begin{tabular}{lrlrlr}
\hline \hline RBC $\left(\times 10^{4} / \mu \mathrm{I}\right)$ & 1280 & TP $(\mathrm{g} / \mathrm{dl})$ & 7.2 & $\mathrm{UN}(\mathrm{mg} / \mathrm{dl})$ & 7.2 \\
$\mathrm{Hb}(\mathrm{g} / \mathrm{dl})$ & 13.2 & A Ib $(\mathrm{g} / \mathrm{dl})$ & 2.6 & $\mathrm{Crea}(\mathrm{mg} / \mathrm{dl})$ & 0.52 \\
$\mathrm{Ht}(\%)$ & 38.3 & A /G & 0.57 & $\mathrm{Mg}(\mathrm{mg} / \mathrm{dl})$ & 1.94 \\
WBC $\left(\times 10^{2} / \mu \mathrm{I}\right)$ & 99 & T -chol $(\mathrm{mg} / \mathrm{dl})$ & 67 & $\mathrm{Na}(\mathrm{mEq} / \ell)$ & 147.4 \\
Band $(\%)$ & 3 & Glu $(\mathrm{mg} / \mathrm{dl})$ & 89 & $\mathrm{~K}(\mathrm{mEq} / \ell)$ & 4.31 \\
Seg $(\%)$ & 37 & A ST $(\mathrm{IU} / \ell)$ & 39 & $\mathrm{Cl}(\mathrm{mEq} / \ell)$ & 103.1 \\
Lymp $(\%)$ & 51 & Y GT $(\mathrm{IU} / \ell)$ & 35 & \\
Mono (\%) & 8 & LDH $(\mathrm{IU} / \ell)$ & 846 & \\
Eosin (\%) & 1 & CPK $(\mathrm{IU} / \ell)$ & 187 & \\
Baso (\%) & 0 & T B $(\mathrm{mg} / \mathrm{dl})$ & 0.25 & \\
& & DB $(\mathrm{mg} / \mathrm{dl})$ & 0.04 & & \\
\hline
\end{tabular}

$\mathrm{RBC}=$ 赤血球数, $\mathrm{Hb}=$ ヘモグロビン值, $\mathrm{Ht}=$ ヘマトクリット值, $\mathrm{WBC}=$ 総白血球数, Band = 桿状核好中球数, Seg $=$ 分葉核好中球数, $L y m p=$ リンパ球数, Mono $=$ 単球数, $E o s i n=$ 好酸球数, Baso = 好塩基球数, $\mathrm{TP}=$ 総蛋白質量, $\mathrm{Al}=$ アルブミン, $\mathrm{A} / \mathrm{G}=$ アルブミン/グロブリン比, T - chol=総コレステロール, Glu=グルコース, A ST = アスパラギン酸 アミノトランスフェラーゼ, y GT = y -グルタミルトランスペプチダーゼ, LDH = 乳酸脱水素酵素, CPK = クレアチン キナーゼ, TB = 総ビリルビン, DB = 直接ビリルビン, UN = 尿素窒素, Crea=クレアチニン, Mg = マグネシウム, Na= ナトリウム, $\mathrm{K}=$ カリウム, $\mathrm{Cl}=$ クロール
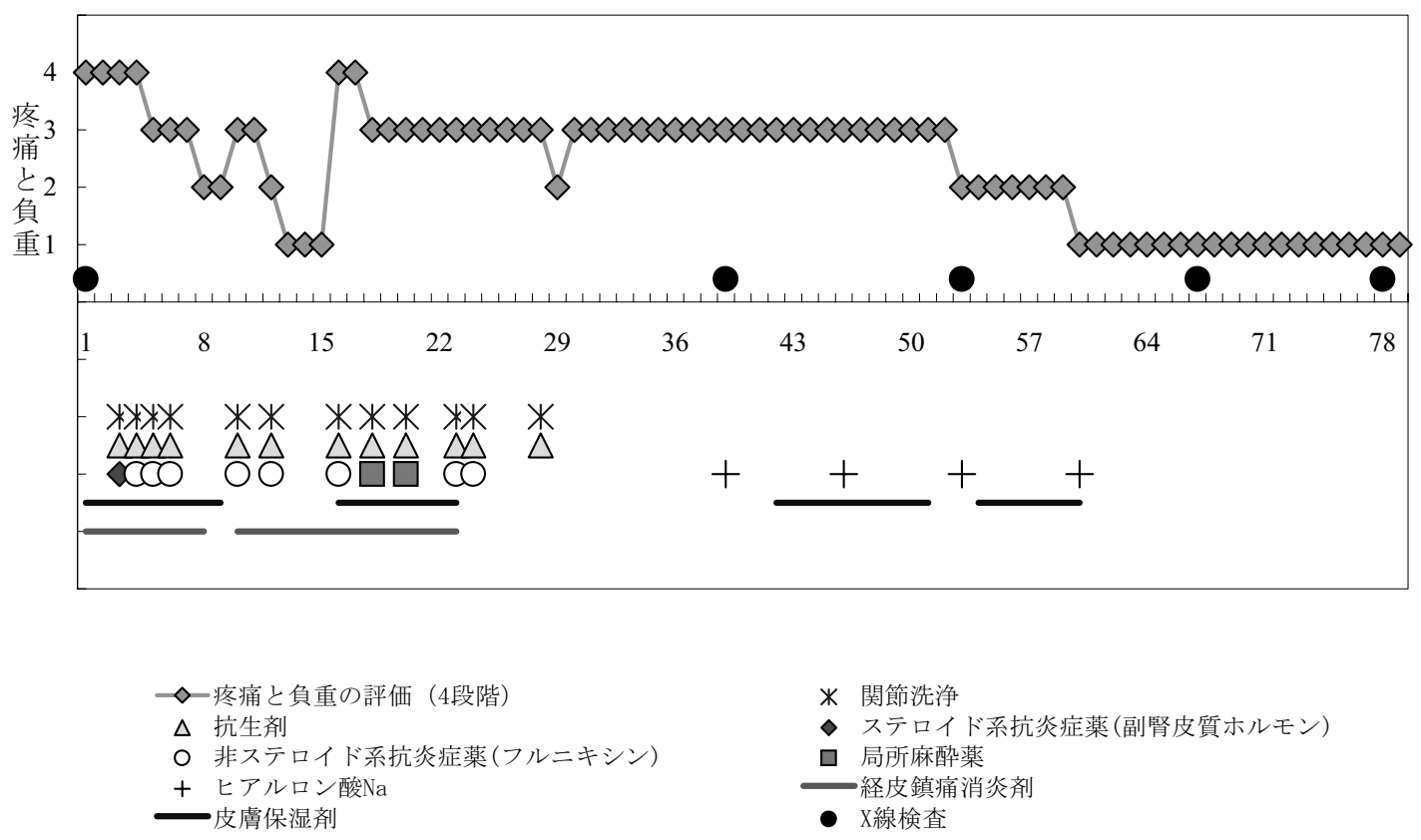

図2．治療の概要、疼痛と負重の評価

变部の除去による骨口 軟骨の再生を期待して関節鏡手術 を行ったロ 塩酸キシラジン (スキルペン $2 \%$ 三共ライ フテックロ 東京) の静脈内投与にて鎮静しロ 関節鏡を用 いて関節内を観察したところロ病変部では軟骨が欠損し て粗造であった口 関節内を乳酸リンゲル液 $(2 \sim 3 \ell)$ で還流しながら口病変部全体の择爬および洗浄を行った 後に縫合しロ ヒアルロン酸ナトリウム (グリオロンロ 日 本藏器製薬口 大阪) $25 \mathrm{mg}$ を関節内に投与した口術後口 血行促進剤を1日1回患部に塗布し口感染症の予防のた めにアンピシリンとクロキサシリンの合剤 (ベテシリンロ 明治製菓口東京) $1 \mathrm{~g}$ 筋肉内投与を 1 日 2 回口術後 2
日間行ったロ またロ ヒアルロン酸ナトリウムの関節内投 与は手術直後を含め 1 週間ごとに合計 4 回行ったロ手術 後 3 日間は患部に疼痛口腫脹口熱感がみられ口患肢は軽 度に負重をする程度であったが 入院43日目（術後4日 目) から腫脹口疼痛は漸减した口入院53日目（術後14日 目) のX線検査所見では口 病変部の状態に変化はみられ なかったが橈側手根骨の一部が遊離している像が新た にみられたロ しかしロ疼痛口跛行は徐々に改善していた ため処置は行わずに経過観察としたロ入院60日目（術後 21日目) から口患部の腫脹がみられなくなったためロ 血 行促進剂の塗布を中止した口 患部に軽度の熱感はみられ 

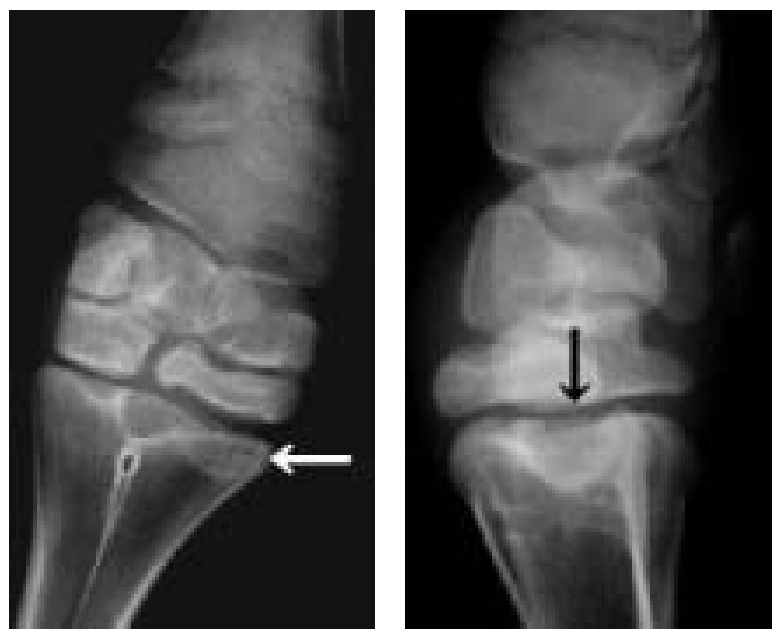

図3，右腕節X線像：入院39日目 (術前) (左：頭尾方向，右：横方向)

矢印：来院時に比べ病変部の拡大がみられる

るが口患肢を伸展しロしつかりと着地口負重をするよう になったロ入院67日目（術後28日目）のX線検査所見で は口 欠損部のX不線透過性亢進像がみられ口骨組織の充 実が起こっていると考えられた（図４）、またロ 橈側手 根骨から遊離した骨片が第二ロ 第三手根骨人再吸収され る像がみられた (図 4) 【同日から 1 日 2 回のリハビリ を行いロ 歩行させる距離を徐々に長くした口 患部の熱感 は漸減し口跛行を示さずに歩行できるようになった口入 院78日目 (術後38日目) のX線検査所見では口 入院67日 目と比べてロ 患部の骨や関節に变化はみられなかった口 疼痛口腫脹口熱感などの症状が改善され口跛行を示さな くなったためロ入院92日目（術後52日目）に退院したロ

\section{考 察}

骨軟骨症では口 骨端軟骨の壊死した血管を中心として 初期の軟骨壊死病変が発生するロ石灰化が壊死軟骨領域 に達すると口軟骨内骨化が局所的に障害を受け口壞死軟 骨の軟骨下骨への波及が起こるロ 多くの初期軟骨壤死病 変は口骨に完全に囲まれて徐々に再吸収され治癒するが 軟骨壞死領域が広範囲である場合は軟骨下骨囊胞が形成 されるロ また口表層の関節軟骨に対する外傷により壊死 した骨端軟骨の脆弱な部分に裂溝が形成され口関節軟骨 を貫き波及すると離断性骨軟骨症の典型的な病変となる [ 3] ] 本症例では骨およひ軟骨の欠損がみられロ 関節内 に骨片が認められなかったことからロ病変部の骨および 軟骨は壞死していたと考えられたロまたロ術後の経過の 中で橈側手根骨の一部が遊離する離断性骨軟骨症の典型 的な病変も認められたロこれらのことからロ本症例は来 院時より骨軟骨症を発症していたと考えられた口
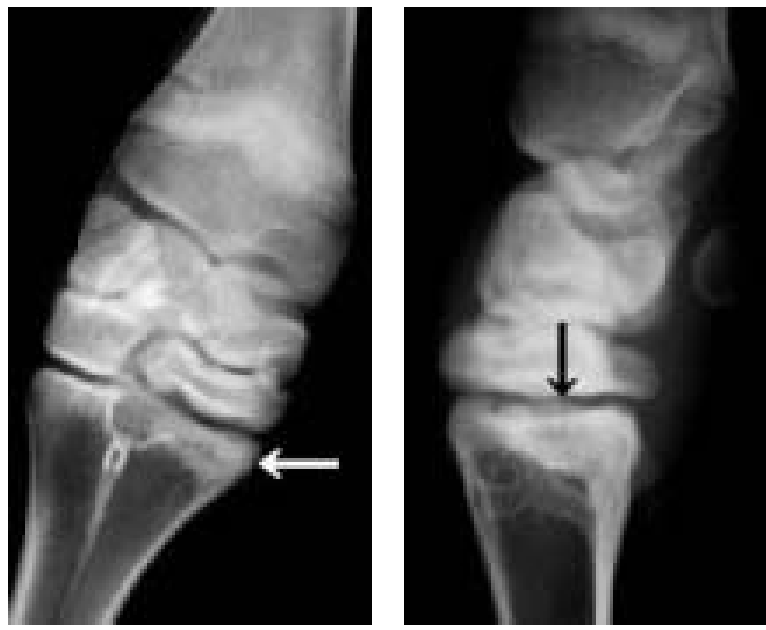

図4，右腕節X線像：入院67日目（術後28日） (左：頭尾方向，右：横方向) 矢印: 術前と比べ病変部の縮小、骨組織の充実がみられる

骨軟骨症の原因は多因的で 外傷口遺伝的要因と急速 な成長口栄養学的要因口虚血などが病因と考えられてい るロ成牛で跛行を示した牛の $8.5 \%$ で膝関節に [ 8]0 7 〜9 ヶ月齢の牛では同じ家系の 5 例で肩関節口 肘関節口 膝関節に [ 7 ] 骨軟骨症の発症がみられたという報告 があるいまたロ 3例の子牛が橈骨近位口中手骨遠位およ び中足骨遠位の関節・骨端軟骨複合体において骨軟骨症 を発症しロうち2 例か壊死軟骨の空洞化を起こしていた という報告や [15]ם 10ケ月齡の牛において2 例で上腕 骨頭に骨軟骨症が発生したという報告がある [13]ם 競 走馬においては口運動時の過負荷と若龄期からの病変の 蓄積が要因となり口中手骨遠位端に外傷性の骨軟骨症が 発症すると報告されている [11] 骨軟骨症の主な症状 としてい初期には関節の腫脹がみられい病変の状態が進 行すると跛行を示す $[7,13] \square$ 本症例での発生部位は口 これらの報告とは異なり口第三中手骨近位端に病変がみ られたが報告されている症例と同樣に関節周囲の腫脹 および患肢の跛行を示していた口今回口発生原因の特定 はできなかったが 若齢では成長段階における四肢の骨 端軟骨に生じた虚血から軟骨組織の壞死 骨化障害が起 こり口骨軟骨症を発症すると報告されており [ 1, 15] 本症例も成長段階の骨端軟骨に生じた虚血から骨軟骨症 を発症した可能性が考えられた口

疼痛の発生は口関節液に存在するブラジキニンなどの 炎症メディエーターか軟骨下骨や滑膜などの侵害受容器 に接触することにより生じ [ 5]ם 骨棘の形成口骨膜の 伸長口骨膜炎口関節内圧の上昇などでも発生すると考え られている [ 1] ヒトの変形性関節症では口 IL-1ß口 T NF-a などの炎症性サイトカインによる軟骨細胞への 
刺激でロ 軟骨組織を破壊する酵素やプロスタグランジン $\mathrm{E}_{2}{ }_{2}$ 増加し口 軟骨組織のプロテオグリカンロ II型コラー ゲンの合成を阻害すると報告されている [ 4, 9]0 また口 関節の洗浄には口 軟骨組織の分解産物口 軟骨組織を破壞 する酵素口 炎症細胞などを除去する効果があるい さらにロ 関節鏡による掻爬では壊死病変の軟骨組織に付着してい る分解産物や炎症細胞を除去して軟骨組織を滑らかにす ることにより口疼痛を引き起こす炎症反応を抑制する効 果がある [6]口 ヒトでは口 骨軟骨症患者に対する関節 の洗浄や変性した軟骨の掻爬手術により口持続的な疼痛 と機能的欠陥の改善がみられたという報告がある [ 6， 14]】本症例では口 注射針を用いた関節洗浄口非ステロ イド系抗炎症剂の関節内投与により一時的な効果は認め られたもののロ 持続した良好な結果は得られなかった口 一方口関節鏡を用いた関節内の洗浄および病変部表面の 掻爬手術では口術後に病変部の縮小がみられ口疼痛口腫 脹口 熱感口跛行などの改善がみられた口関節鏡を用いた 関節洗浄と掻爬により口関節内の軟骨組織に付着してい た分解産物や壊死病変を除去し軟骨組織を滑らかにした ことによってロ 軟骨組織の炎症反応が抑制され疼痛が漸 減し口症状の改善に至ったと考えられたロ 一方口非ステ ロイド系抗炎症剂の関節内投与では口壊死病変が進行し ていたことからロ 軟骨組織における炎症細胞や分解産物 による炎症反応を抑制できずロ 良好な効果を示さなかつ た可能性が考えられた口これらのことからロ 関節液に含 まれる炎症メディエーターなどが原因で疼痛が生じてい たのではなく、軟骨組織の変性口壊死によって疼痛が生 じていたと考えられたロ

ヒアルロン酸は口 N-アセチルグルコサミンとグルク ロン酸が交互に結合した酸性高分子多糖で 結合織に分 布するほか、硝子体口関節液口臍帯などに存在する、粘 滑剂として働いている以外に口 組織の水分代謝や構造の 維持に役立っているい 関節においては滑膜と関節液の主 な成分であり [10]ם 衝撃吸収の役割を果たす [ 6, 9]ם またロ プロテオグリカンの構成成分としてロ コラーゲン と結合し軟骨細胞に分布する [ 6] ヒアルロン酸の投 与はサイトカインやプロスタグランジン $\mathrm{E}_{2}$ などの炎症 メディエーターの分泌や，炎症細胞の浸潤を抑制するこ とによって軟骨組織の変性を防ぎロ 関節液中のプロテオ グリカン合成や軟骨組織の再生を促進する作用があるい そのためロヒトにおいては変形性関節症や骨軟骨症口リ ウマチの治療などに用いられている [ 9]0 ラットにお けるヒアルロン酸ナトリウムの関節内投与は口 ブラジキ ニンなどの内因性発痛物質の関節内投与による疼痛を抑
制する働きがあるとされ [ 5] ヒトにおいては関節鏡 洗浄後のヒアルロン酸ナトリウムの関節内投与は口 長期 間 ( 1 〜 年) 治療効果を保つのに有効であるという報 告がある [ 6]ם これらのことからヒアルロン酸ナトリ ウムの関節内投与は口 軟骨組織における炎症メディエー ターの分泌や炎症細胞の浸潤抑制口軟骨組織の修復や保 護口 粘弾性の回復に寄与し口疼痛の改善に至ったと考え られたロ

本症例は軟骨下骨の囊胞状欠損を伴う骨軟骨症に罹患 しており口関節の洗浄と非ステロイド系抗炎症剂などの 消炎剂による治療のみでは口 持続した良好な効果はみら れなかった口しかしロ関節鏡による掻爬とヒアルロン酸 ナトリウムの関節内投与により疼痛など症状の改善がみ られたことから口牛においても骨軟骨症の有効な治療法 であると考えられたロ

\section{引用文献}

1. Barron MC, Rubin BR (2007) Managing osteoarthritic knee pain. J Am Osteopath A ssoc, 107 (Suppl 6) : ES21-27

2. Calmbach WL, Hutchens M (2003) Evaluation of patients presenting with knee pain : Part II. Differential diagnosis. A m Fam Physician. 68: 917-922

3. Ekman S, Carlson CS (2000) 獣医臨床シリーズ vol.26 No.6 骨軟骨症. (富沢伸行訳), 13-25, 学悹社, 東京

4. Kojima F, Naraba H, Miyamoto S, Beppu M, A oki H, Kawai S (2004) Membrane-assodiated prostaglandin E synthase-1 is upregulated by proinflammatory cytokines in chondrocytes from patients with osteoarthritis. A rthritis Res Ther, 6 : 355-365

5. 後藤幸子, 宮崎匡輔, 女屋純一, 坂本 崇, 徳安清 親，並木 脩 (1988) ラットにおける実験的関節疼痛 モデルとヒアルロン酸ナトリウムの鎮痛作用. 日薬理 誌, $92: 17-27$

6. Hempfling H (2007) Intra-articular hyaluronic acid after knee arthroscopy:a tw o-y ear study. Knee Surg Sports Traumatol A rthrosc, 15 : 537-546

7. Hill BD, Sutton RH, Thompson H (1998) Investigation of osteochondrosis in grazing beef cattle. A ust $V$ et $J, 76: 171-175$

8. Jensen R, Park RD, Lauerman LH, Braddy PM, Horton DP, Flack DE, Cox MF, Einertson N, Miller 
GK, Rehfeld CE ( 1981) Osteochondrosis in feedlot cattle. V et Pathol, $18: 529-535$

9. Moreland LW (2003) Intra-articular hyaluronan (hyaluronic acid) and hylans for the treatment of osteoarthritis : mechanisms of action. A rthritis Res Ther, $5: 5467$

10. Nakayama $Y$, Shirai $Y, Y$ oshihara K, Uesaka S (2000) Evaluation of glycosaminoglycans levels in normal joint fluid of the knee. J Nippon Med Sch, 67 : 92-95

11. Norrdin RW, Stover SM (2006) Subchondral bone failure in overload arthrosis: A scanning electron microscopic study in horses. J Musculoskelet Neuronal Interact, $6:$ 251-257

12. Riley CB, Scott WM, Caron JP, Fretz PB, Bailey JV, Barber SM (1998) Osteochondritis dessicans and subchondral cystic lesions in draft horses: A retrospective study. Can V et J, $39: 627-633$

13. Scott PR, Rhind S, Brownstein D (2000) Severe osteochondrosis in two 10-month-old beef calves. $V$ et Rec, $147: 608-609$

14. V an Oosterhout M, Sont JK, V an Laar JM (2003) Superior effect of arthroscopic lavage compared with needle aspiration in the treatment of inflammatory arthritis of the knee. Rheumatology, 42 : 102-107

15. Wegener KM, Heje NI (1992) Dyschondroplasia (Osteochondrosis) in articular-epiphyseal cartilage complex of three calves from 24 to 103 days of age. $V$ et Pathol, $29: 562-563$ 